\title{
Penerapan Logika Fuzzy Metode Mamdani Dalam Menyelesaikan Masalah Produksi Garam Nasional
}

\author{
Yulia Retno Sari**1, Maha Rani ${ }^{2}$ \\ 1,2 Jurusan Sistem Informasi, Fakultas Ilmu Komputer, UPI YPTK Padang \\ e-mail: *1yuliaretnosari2012@gmail.com, ${ }^{2}$ ranimaha1405@gmail.com
}

\begin{abstract}
Abstrak
Indonesia merupakan negara maritim. Negara yang memiliki garis pantai nomor dua terpanjang di dunia. Dengan garis pantai yang panjang, Indonesia dapat menghasilkan sumber daya alam laut yang berlimpah contohnya garam. Garam adalah komoditi strategis, dikatakan strategis karena garam dibutuhkan untuk konsumsi, industri, farmasi dan pengeboran minyak. Merujuk pada neraca garam nasional yang dikeluarkan Kementrian Kelautan dan Perikanan (KKP) pada tahun 2014 dinyatakan percepatan kenaikan rata-rata konsumsi garam berbanding terbalik dengan jumlah produksi garam nasional yang dihasilkan tiap tahunnya. Penelitian ini bertujuan untuk memprediksi jumlah produksi garam nasional menggunakan logika fuzzy metode mamdani. Hasil prediksi yang diperoleh adalah 1.400 .000 ton per-tahunnya. Jumlah produksi yang akan diprediksi memiliki variabel - variabel independen yaitu curah hujan, luas lahan dan kebutuhan garam. Dengan mempelajari faktor-faktor yang mempengaruhi jumlah produksi garam tersebut maka dianalisa bahwa variabel independen dapat menjelaskan variasi jumlah produksi garam sebesar 53\% sedangkan sisanya diterangkan oleh variabel lain. Oleh karena itu ketiga variabel tersebut harus dioptimalkan melalui cara intensifikasi dan ekstensifikasi yang pastinya harus didukung dengan kebijakan - kebijakan yang diterbitkan oleh pemerintah.
\end{abstract}

Kata $\mathbf{k u n c i}$ - logika fuzzy, metode mamdani, jumlah produksi garam, masalah produksi garam nasional

\begin{abstract}
Indonesia is a maritime country. It is a country which has the second longest coastline in the world. With the long coastline, Indonesia can produce abundant marine natural resources like salt. Salt is a strategic commodity since it is needed to consumption, industry, pharmacy and oil drilling. Referring to the national salt balance issued by The Ministry of Marine Affairs and Fisheries (KKP) in 2014, it is stated that the acceleration of the increase in average salt consumption is inversely propotional to the amount of national salt production that is produced each year. This study is aimed to predict the amount of national salt production by using Mamdani Fuzzy logic method. The prediction result obtained are 1.400.000 tons in every year. The amount of production that will be predicted has independent variables namely rainfall, land area and salt requirements. By studying the factors that influence the amount of salt production, it is analyzed that the independent variable can explain the variation in the amount of salt production by 53\% while the rest is explained by other variables. Therefore, these three variables must be optimized throught intensification and extensification which of course must be supported by policies issued by the government.
\end{abstract}

Keywords - fuzzy logic, mamdani method, the amount of salt production, problem of national salt production 


\section{PENDAHULUAN}

$\mathrm{G}$ aram merupakan komoditi strategis yang diperlukan untuk kebutuhan konsumsi, sebagai bahan baku industri, makanan olahan, industri kimia atau farmasi, industri penyamakan kulit dan industri pengeboran minyak. Jika merujuk pada neraca garam nasional yang dikeluarkan Kementrian Kelautan dan Perikanan (KKP) pada tahun 2014 kebutuhan garam nasional mencapai 3,61 juta ton. Konsumsi 1,48 juta ton dan Industri 2,13 juta [1]. Kenaikan rata-rata sebesar 1,4 persen pertahun dan untuk garam industri 5,8 persen pertahun. Percepatan kenaikan rata-rata konsumsi garam berbanding terbalik dengan jumlah produksi garam nasional yang dihasilkan tiap tahunnya. Produksi garam nasional belum mampu memenuhi kebutuhan dalam negeri. Selama 15 tahun ini pemerintah masih mengimpor garam dari luar negeri.

Dalam proses produksi garam masih menggunakan cara konvensional dengan memanfaatkan sinar matahari, angin dan lain-lain. Hal ini berdampak pada produktivitas yang rendah dan kualitas yang relatif rendah pula. Garam yang dihasilkan petambak garam nasional memiliki kadar klor $(\mathrm{NaCl})$ minimal 94,7 persen. Untuk garam konsumsi (garam meja) memiliki $\mathrm{NaCl}$ minimal 94,7 persen dan sudah dapat dipenuhi oleh produsen lokal. Tetapi untuk garam kebutuhan industri dengan $\mathrm{NaCl}$ minimal 97 persen hanya dapat dipenuhi oleh garam impor. Karena kualitas yang relatif rendah menyebabkan harga garam untuk kebutuhan konsumsi sangat murah dibandingkan dengan garam impor [1]. Ditambah lagi dengan rantai distribusi garam yang panjang sehingga harga jual garam dikalangan petambak jauh lebih

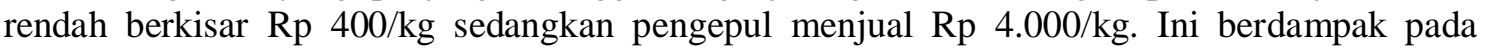
kesejahteraan petambak garam nasional itu sendiri. Produsen garam nasional adalah PT. Garam (BUMN) dan masyarakat petambak garam. Dengan hasil produksi terbesarnya adalah masyarakat petambak garam. Tetapi berbanding terbalik dengan tingkat kesejahteraan mereka [2].

Penelitian ini bertujuan untuk memprediksi jumlah produksi garam nasional menggunakan logika fuzzy metode mamdani dan regresi linier berganda metode kuadrat terkecil (least squares method) digunakan untuk melihat keterikatan variabel - variabel independennya. Kedua metode tersebut dapat digunakan untuk memprediksi jumlah produksi garam nasional. Jumlah produksi garam yang akan diprediksi memiliki variabel terikat dan variabel bebas. Dengan mempelajari faktor-faktor yang mempengaruhi jumlah produksi garam maka akan diperoleh jumlah produksi garam nasional yang maksimal.

\section{METODE PENELITIAN}

\section{1 Logika Fuzzy}

Suatu istilah dikatakan fuzzy (kabur) apabila istilah tersebut tidak dapat didefinisikan secara tegas atau pasti sehingga membutuhkan adanya penegasan. Logika fuzzy adalah suatu cara yang tepat untuk memetakan ruang input ke dalam suatu ruang output. Logika fuzzy pertama kali diperkenalkan oleh Prof. L.A. Zadeh (1965) [3]. Kalau himpunan crisp (tegas), nilai keanggotaan hanya ada dua kemungkinan, yaitu 0 atau 1, sedangkan himpunan fuzzy nilai keanggotaan terletak pada rentang 0 sampai 1. Apabila $x$ memiliki nilai keanggotaan fuzzy $\mu_{\mathrm{A}}[x]=0$ berarti $x$ tidak menjadi himpunan $\mathrm{A}$, demikian pula apabila $x$ memiliki nilai keanggotaan fuzzy $\mu_{\mathrm{A}}[x]=1$ berarti $x$ menjadi anggota penuh himpunan A [4]. Himpunan fuzzy memiliki 2 atribut, yaitu:

a. Linguistik, yaitu penamaan suatu group yang mewakili suatu keadaan atau kondisi tertentu dengan menggunakan bahasa alami.

b. Numeris, yaitu suatu nilai (angka) yang menunjukkan ukuran dari suatu variabel.

Fungsi keanggotaan (membership function) adalah suatu kurva yang menunjukkan pemetaan titik-titik input data ke dalam nilai keanggotaan yang memiliki interval antara 0 
sampai 1. Salah satu cara yang dapat digunakan untuk mendapatkan nilai keanggotaan adalah dengan melalui pendekatan fungsi. Ada beberapa fungsi yang bisa digunakan ; Representasi Linier, Representasi Kurva Segitiga, Representasi Kurva Trapesium, Representasi Kurva Bentuk Bahu, Representasi Kurva-S dan Representasi Kurva Bentuk Lonceng (Bell Curve) [5].

Seperti halnya himpunan konvensional, ada beberapa operasi yang didefinisikan secara khusus untuk mengkombinasi dan memodifikasi himpunan fuzzy. Nilai keanggotaan sebagai hasil dari operasi dua himpunan sering dikenal dengan nama fire strength atau $\alpha$-predikat. Ada tiga operator dasar yang diciptakan oleh Zadeh, yaitu : Operator AND, Operator OR dan Operator NOT [6].

\subsection{Fungsi Implikasi}

Tiap-tiap aturan (proposisi) pada basis pengetahuan fuzzy akan berhubungan dengan suatu relasi fuzzy. Bentuk umum dari aturan yang digunakan dalam fungsi implikasi adalah

$$
\text { IF } x \text { is } A \text { THEN } y \text { is } B
$$

dengan $\mathrm{x}$ dan y adalah skalar, A dan B adalah himpunan fuzzy. Proposisi yang mengikuti IF disebut sebagai anteseden, sedangkan proposisi yang mengikuti THEN disebut sebagai konsekuen. Proposisi ini dapat diperluas dengan menggunakan operator fuzzy, seperti:

$$
\text { IF }\left(x_{1} \text { is } A_{1}\right) \circ\left(x_{2} \text { is } A_{2}\right) \circ\left(x_{3} \text { is } A_{3}\right) \circ \ldots \circ\left(x_{n} \text { is } A_{n}\right) \text { THEN } y \text { is } B \text {. }
$$

dengan $\circ$ adalah operator (misal: OR dan AND). Secara umum, ada 2 fungsi implikasi yang dapat digunakan, yaitu:

a. Min (minimum).

Fungsi ini akan memotong output himpunan fuzzy.

b. Dot (product)

Fungsi ini akan menskala output himpunan fuzzy.

\subsection{Metode Mamdani}

Metode Mamdani sering dikenal sebagai Metode Max-Min. Metode ini diperkenalkan oleh Ebrahim Mamdani pada tahun 1975. Untuk mendapatkan output, diperlukan 4 tahapan [7]:

a. Pembentukan himpunan fuzzy

Pada Metode Mamdani, baik variabel input maupun variabel output dibagi menjadi satu atau lebih himpunan fuzzy.

b. Aplikasi fungsi implikasi

Pada Meode Mamdani, fungsi implikasi yang digunakan adalah Min.

c. Komposisi Aturan

Ada 3 metode yang digunakan dalam melakukan inferensi sistem fuzzy, yaitu max, additive dan probabilistic OR (probor). Dalam penelitian ini penulis menggunakan Metode Max (maximum). Pada metode ini, solusi himpunan fuzzy diperoleh dengan cara mengambil nilai maksimum aturan, kemudian menggunakannya untuk memodifikasi daerah fuzzy dan mengaplikasikannya ke output dengan menggunakan operator OR (union). Jika semua proposisi telah dievaluasi, maka output akan berisi suatu himpunan fuzzy yang merefleksikan konstribusi dari tiap-tiap proposisi. Secara umum dapat ditulis:

$$
\mu_{s f}\left(x_{i}\right)=\max \left(\mu_{s f}\left(x_{i}\right), \mu_{k f}\left(x_{i}\right)\right)
$$

dengan: $\mu_{s f}\left(x_{i}\right)=$ nilai keanggotaan solusi fuzzy sampai aturan ke $-\mathrm{i}$ dan $\mu_{k f}\left(x_{i}\right)=$ nilai keanggotaan konsekuen fuzzy aturan ke-i. 
d. Penegasan (defuzzy)

Input dari proses defuzziffikasi adalah suatu himpunan fuzzy yang diperoleh dari komposisi aturan-aturan fuzzy, sedangkan output yang dihasilkan merupakan suatu bilangan pada domain himpunan fuzzy tersebut. Sehingga jika diberikan suatu himpunan fuzzy dalam range tertentu, maka harus dapat diambil suatu nilai crisp tertentu sebagai output.

\subsection{Regresi Linier Berganda}

Dalam regresi linier berganda, peramalan nilai variabel dependen $(Y)$ diperoleh dengan membentuk persamaan yang menghubungkan lebih dari satu variabel independen yaitu $x_{1}, x_{2}, \ldots, x_{n}$. Secara umum persamaan regresi berganda dapat dirumuskan dengan:

$$
\hat{Y}_{i}=p_{0}+p_{1} x_{1 i}+p_{2} x_{2 i}+\cdots+p_{n} x_{n i}+\varepsilon
$$

Penelitian ini terdiri atas satu variabel tidak bebas $\mathrm{Y}$ dan tiga variabel bebas $\mathrm{X}$ yaitu $x_{1}, x_{2}, x_{3}$. Maka persamaan regresi bergandanya adalah:

$$
\hat{Y}_{i}=p_{0}+p_{1} x_{1 i}+p_{2} x_{2 i}+p_{3} x_{3 i}+\varepsilon
$$

Nilai koefisien $p_{0}, p_{1}, p_{2}$ dan $p_{3}$ dapat diperoleh dengan metode kuadrat terkecil (least squares method), dengan cara terlebih dahulu meminimumkan jumlah kuadrat sisa sebagai berikut :

$$
S=\sum_{i=1}^{n} e_{i}^{2}=\sum_{i=1}^{n}\left(Y_{i}-\hat{Y}_{i}\right)^{2}=\sum_{i=1}^{n}\left(Y_{i}-p_{0}-p_{1} x_{1 i}-p_{2} x_{2 i}-p_{3} x_{3 i}\right)^{2}=0
$$

Kemudian persamaan (4) dideferensialkan terhadap masing-masing koefisien $p_{0}, p_{1}, p_{2}$ dan $p_{3}$ maka diperoleh persamaan - persamaan berikut [8]:

$$
\sum_{i=1}^{n} x_{3 i} Y_{i}=p_{0} \sum_{i=1}^{n} x_{3 i}+p_{1} \sum_{i=1}^{n} x_{1 i} x_{3 i}+p_{2} \sum_{i=1}^{n} x_{2 i} x_{3 i}+p_{3} \sum_{i=1}^{n} x_{3 i}^{2}
$$

Dalam penelitian ini data yang digunakan adalah data sekunder dari Badan Pusat Statistika (BPS),Kementrian Kelautan dan Perikanan dan Ditjen PRL - KKP. Data tersebut dapat dilihat pada table 1 dibawah ini :

Tabel 1. Data Curah Hujan, Luas Lahan, Kebutuhan Garam dan Produksi Garam Nasional Tahun $2010-2019$

\begin{tabular}{|c|c|c|c|c|}
\hline Tahun & $\begin{array}{c}\text { Curah } \\
\text { Hujan }(\mathbf{m m})\end{array}$ & $\begin{array}{c}\text { Luas Lahan } \\
\text { (Ha) }\end{array}$ & $\begin{array}{c}\text { Kebutuhan } \\
\text { Garam (Ton) }\end{array}$ & $\begin{array}{c}\text { Produksi Garam } \\
\text { Nasional (Ton) }\end{array}$ \\
\hline $\mathbf{2 0 1 0}$ & 689 & 20.000 & 3.003 .550 & 30.600 \\
\hline $\mathbf{2 0 1 1}$ & 228,15 & $24.139,94$ & 3.228 .750 & 1.113 .118 \\
\hline $\mathbf{2 0 1 2}$ & 107,75 & $26.975,44$ & 3.270 .086 & 2.017 .601 \\
\hline $\mathbf{2 0 1 3}$ & 340 & $29.367,82$ & 3.573 .954 & 1.087 .715 \\
\hline $\mathbf{2 0 1 4}$ & 119 & 27.898 & 3.532 .719 & 2.192 .168 \\
\hline $\mathbf{2 0 1 5}$ & 39,60 & 25.875 & 3.750 .284 & 2.800 .000 \\
\hline $\mathbf{2 0 1 6}$ & 594,30 & 12.560 & 3.500 .000 & 118.000 \\
\hline $\mathbf{2 0 1 7}$ & 365,60 & 26.000 & 3.900 .000 & 1.100 .000 \\
\hline $\mathbf{2 0 1 8}$ & 78 & 26.000 & 4.000 .000 & 2.300 \\
\hline $\mathbf{2 0 1 9}$ & 31,70 & $27.048,65$ & 4.200 .000 & 2.775 .447 \\
\hline
\end{tabular}


Tahapan-tahapan yang dilakukan dalam penelitian ini adalah:

a. Pembentukan himpunan fuzzy.

Pada Metode Mamdani, variabel input dan variabel output dibagi menjadi satu atau lebih himpunan fuzzy.

b. Aplikasi fungsi implikasi.

Pada Metode Mamdani, fungsi implikasi yang digunakan adalah Min.

c. Penegasan (defuzzy).

Proses penegasan (defuzzyfikasi) menggunakan bantuan software Matlab dengan memanfaatkan fasilitas yang disediakan pada toolbox fuzzy. Pada tahap ini diperoleh prediksi Jumlah Garam Nasional.

d. Menganalisa faktor - faktor yang mempengaruhi produksi garam nasional dengan Regresi Linier Berganda metode Kuadrat Terkecil.

Metode ini kami gunakan karena kami akan menguji seberapa besar keterikatan faktor faktor independen yang mempengaruhi jumlah garam nasional. Dalam perhitungannya kami menggunakan software Minitab. Setelah didapat persamaan linier dari Minitab maka kami mensubtitusikan semua nilai variabel bebas sehingga menghasikan variabel terikat yang merupakan prediksi produksi garam nasional.

Dapat digambarkan seperti gambar 1 di bawah ini :

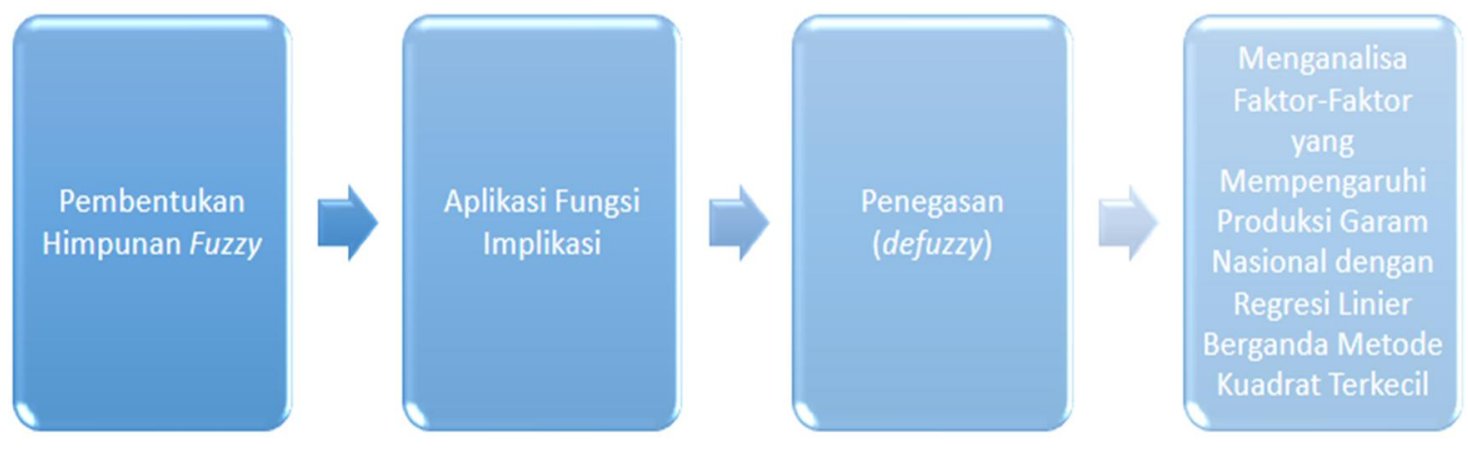

Gambar 1. Tahapan Penelitian

\section{HASIL DAN PEMBAHASAN}

Terdapat beberapa tahapan yang akan dilakukan untuk memprediksi Produksi Garam Nasional. Metode yang digunakan ada dua yaitu Logika Fuzzy metode Mamdani yang dikenal dengan metode Max-Min dan Analisis Regresi Linier Berganda metode Kuadrat Terkecil. Untuk mengefisiensikan waktu, peneliti menggunakan software Matlab dan Minitab. Untuk mendapatkan output maka kita mulai saja tahapan analisanya;

a. Pembentukan Himpunan Fuzzy

Langkah pertama dari tahapan ini adalah pembentukan himpunan Fuzzy. Ada 4 variabel yang akan dibentuk group himpunannya yaitu curah hujan, luas lahan, kebutuhan garam dan produksi garam nasional. Untuk variabel curah hujan, himpunan Fuzzynya adalah rendah, sedang dan tinggi. Variabel luas lahan himpunan Fuzzynya yaitu kecil, sedang dan besar. Variabel kebutuhan garam himpunan Fuzzynya sebagai berikut rendah dan tinggi. Dan variabel terakhir, produksi garam nasional himpunan Fuzzynya adalah sedikit, sedang dan banyak. 
Tabel 2. Penentuan variabel dan Semesta Pembicaraan

\begin{tabular}{|c|c|c|c|}
\hline \multirow{2}{*}{ Fungsi } & Variabel & $\begin{array}{c}\text { Semesta } \\
\text { Pembicaraan }\end{array}$ & Keterangan \\
\hline \multirow{3}{*}{ Input } & Curah Hujan & $31,7-689$ & Curah Hujan (mm) \\
\cline { 2 - 4 } & Luas Lahan & $12.560-29.367,82$ & Luas Lahan (Hektar) \\
\cline { 2 - 4 } & Kebutuhan Garam & $3.003 .550-4.200 .000$ & $\begin{array}{c}\text { Kebutuhan Garam } \\
\text { (Ton) }\end{array}$ \\
\hline \multirow{2}{*}{ Output } & $\begin{array}{c}\text { Produksi Garam } \\
\text { Nasional }\end{array}$ & $2.300-2.800 .000$ & $\begin{array}{c}\text { Produksi Garam } \\
\text { Nasional (Ton) }\end{array}$ \\
\hline
\end{tabular}

Menentukan domain curah hujan, luas lahan, kebutuhan garam dan produksi garam nasional pada tabel 3 dibawah ini:

Tabel 3. Himpunan Fuzzy, Semesta Pembicara dan Domain

\begin{tabular}{|c|c|c|c|c|}
\hline Fungsi & Variabel & $\begin{array}{c}\text { Nama } \\
\text { Himpunan } \\
\text { Fuzzy }\end{array}$ & Semesta Pembicara & Domain \\
\hline \multirow{8}{*}{ Input } & \multirow{3}{*}{ Curah Hujan } & Rendah & \multirow{3}{*}{$31-689$} & $31-360$ \\
\hline & & Sedang & & $250-469$ \\
\hline & & Tinggi & & $360-689$ \\
\hline & \multirow{3}{*}{ Luas Lahan } & Kecil & \multirow{3}{*}{$12.560-29.368$} & $12.500-20.964$ \\
\hline & & Sedang & & $18.163-23.766$ \\
\hline & & Besar & & $20.964-29.368$ \\
\hline & \multirow{2}{*}{ Kebutuhan Garam } & Rendah & \multirow{2}{*}{$33.003 .550-4.200 .000$} & $3.003 .550-3.601 .800$ \\
\hline & & Tinggi & & $3.601 .800-4.200 .000$ \\
\hline \multirow{3}{*}{ Output } & \multirow{3}{*}{ Produksi Garam } & Sedikit & \multirow{3}{*}{$2.300-2.800 .000$} & $2.300-1.401 .150$ \\
\hline & & Sedang & & $934.867-1.867 .434$ \\
\hline & & Banyak & & $1.401 .150-2.800 .000$ \\
\hline
\end{tabular}

(i) Curah Hujan

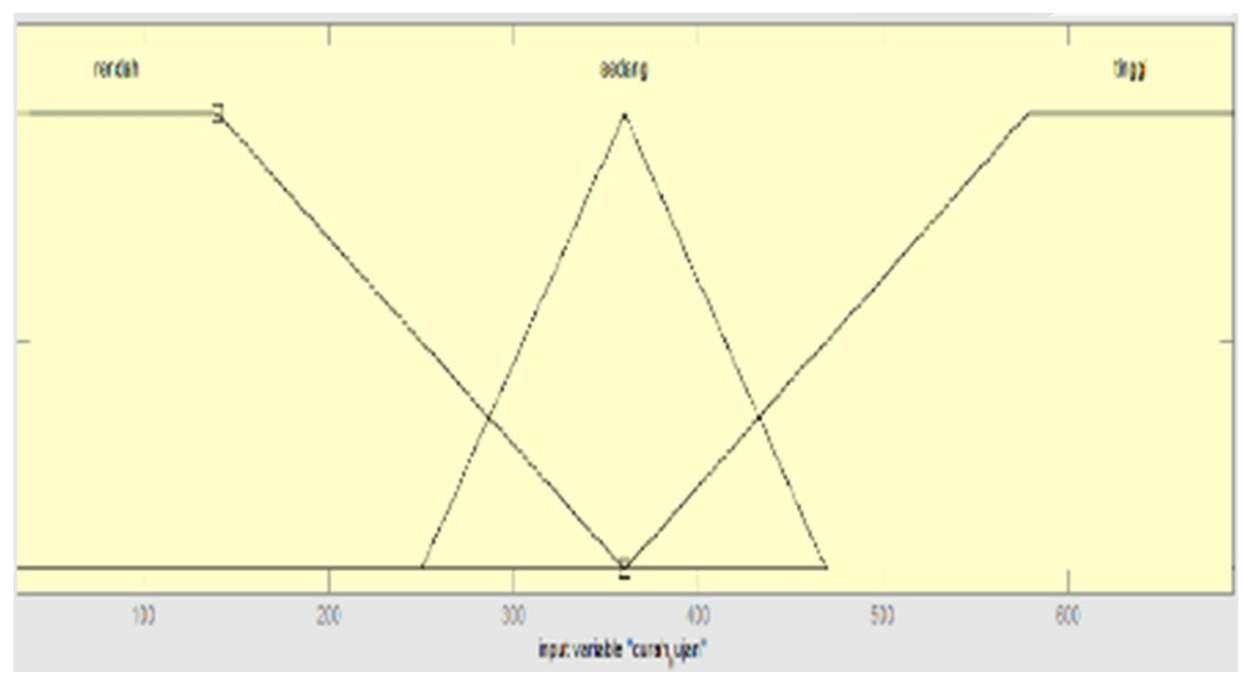

Gambar 2. Kurva Himpunan Fuzzy Untuk Variabel Curah Hujan Atau Representasi Variabel Curah Hujan 
Fungsi keanggotaan:

$$
\begin{aligned}
& \mu_{\text {Curah Hujan Rendah }}[x]=\left\{\begin{array}{l}
1 ; x \leq 140 \\
\frac{360-x}{220} ; 140 \leq x \leq 360 \\
0 ; x \geq 360
\end{array}\right. \\
& \mu_{\text {Curah Hujan Sedang }}[x]=\left\{\begin{array}{l}
0 ; x \leq 250 \text { atau } x \geq 469 \\
\frac{x-250}{109} ; 250 \leq x \leq 360 \\
\frac{360-x}{110} ; 360 \leq x \leq 469
\end{array}\right.
\end{aligned}
$$

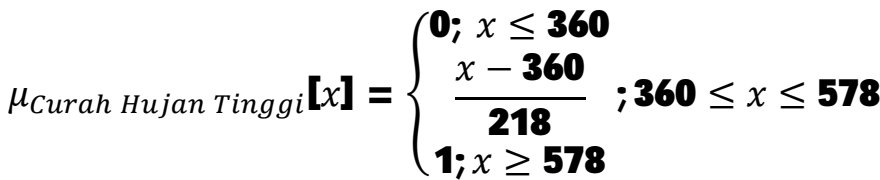

Jika curah hujan sebesar 31,7 mm, maka nilai keanggotaan ( $\left.\mu_{\text {Curah Hujan }}[31,7]\right)$ pada tiap-tiap himpunan adalah

$$
\begin{aligned}
& \mu_{\text {Curah Hujan Rendah }}[31,7]=1 \\
& \mu_{\text {Curah Hujan Sedang }}[31,7]=0 \\
& \mu_{\text {Curah Hujan Tinggi }}[31,7]=0
\end{aligned}
$$

(ii) Luas Lahan

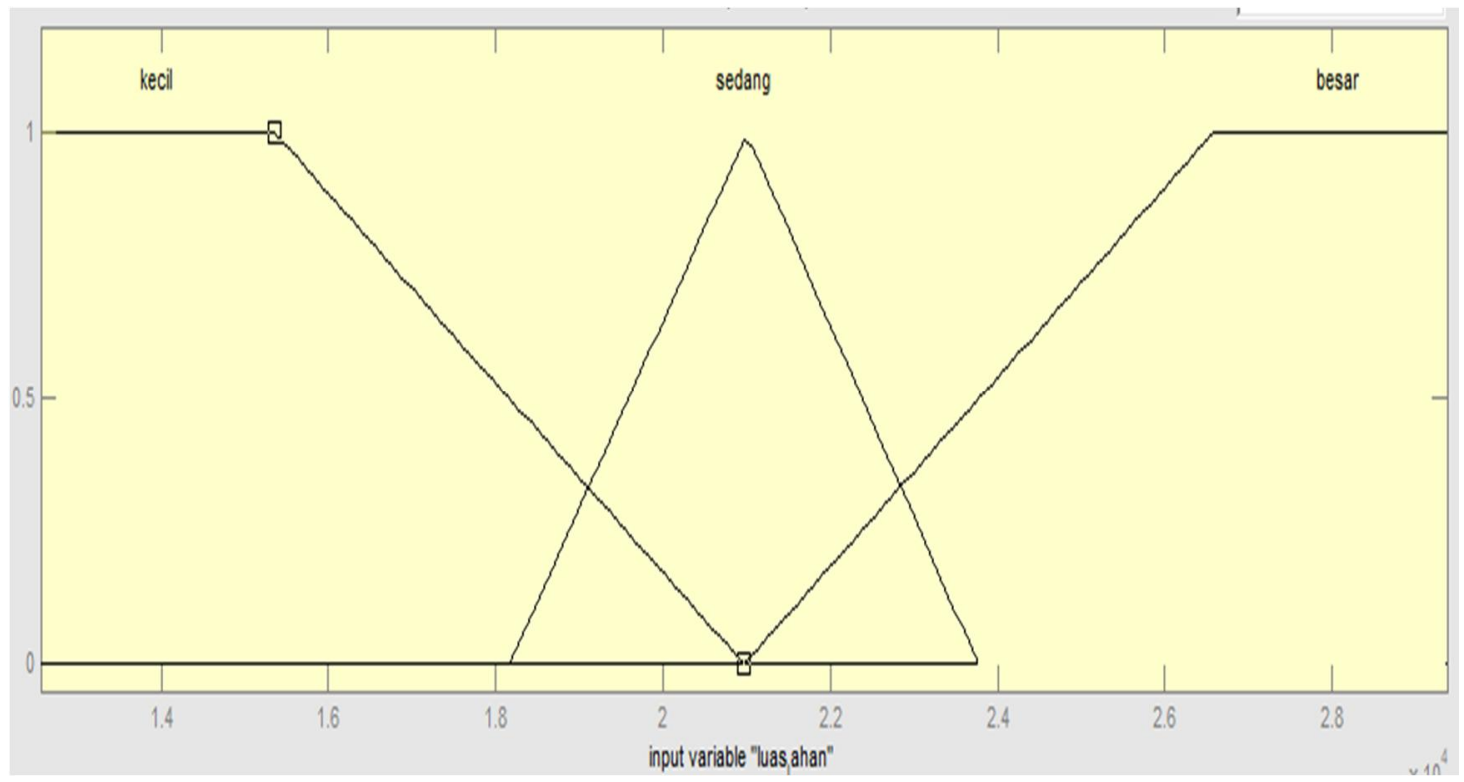

Gambar 3. Kurva Himpunan Fuzzy Untuk Variabel Luas Lahan Atau Representasi Variabel Luas Lahan 
Fungsi keanggotaan:

$$
\begin{aligned}
& \mu_{\text {Luas Lahan Kecil }}[x]=\left\{\begin{array}{l}
1 ; x \leq 15.362 \\
\frac{20.964-x}{5.604} ; 15.362 \leq x \leq 20.964 \\
0 ; x \geq 20.964
\end{array}\right. \\
& \mu_{\text {Luas Lahan Sedang }}[x]=\left\{\begin{array}{l}
0 ; x \leq 18.163 \text { atau } x \geq 23.766 \\
\frac{x-18.163}{2.801} ; 18.163 \leq x \leq 20.964 \\
\frac{20.964-x}{2.802} ; 20.964 \leq x \leq 23.766
\end{array}\right. \\
& \mu_{\text {Luas Lahan Besar }}[x]=\left\{\begin{array}{l}
0 ; x \leq 20.964 \\
\frac{x-20.964}{5604} ; 20.964 \leq x \leq 26.568 \\
1 ; x \geq 26.568
\end{array}\right.
\end{aligned}
$$

Jika luas lahan tambak sebesar 27.047,65 Ha, maka nilai keanggotaan ( $\left.\mu_{\text {Luas Lahan }}[27.047,65]\right)$ pada masing-masing himpunan adalah

$$
\begin{gathered}
\mu_{\text {Luas Lahan Kecil }}[27.047,65]=0 \\
\mu_{\text {Luas Lahan Sedang }}[27.047,65]=0 \\
\mu_{\text {Luas Lahan Besar }}[27.047,65]=1
\end{gathered}
$$

(iii) Kebutuhan Garam

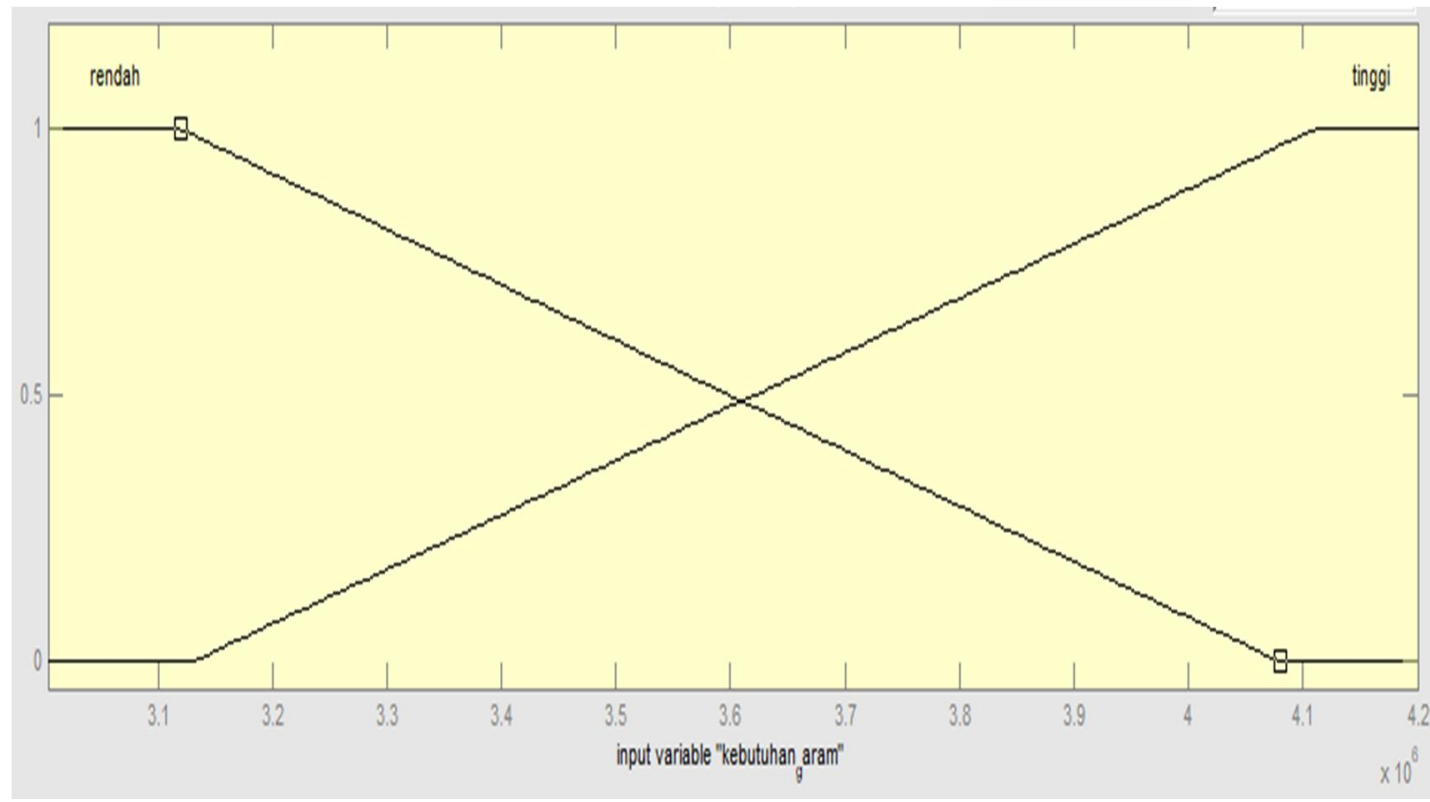

Gambar 4. Kurva Himpunan Fuzzy Untuk Variabel Kebutuhan Garam 
Fungsi keanggotaan:

$$
\begin{aligned}
& \mu_{\text {Kebutuhan Garam Rendah }}[x]=\left\{\begin{array}{l}
1 ; x \leq 3.003 .550 \\
\frac{4.200 .000-x}{1.196 .450} ; 3.003 .550 \leq x \leq 4.200 .000 \\
0 ; x \geq 4.200 .000
\end{array}\right. \\
& \mu_{\text {Kebutuhan Garam Tinggi }}[x]=\left\{\begin{array}{l}
0 ; x \leq 3.003 .550 \\
\frac{x-3.003 .550}{1.196 .450} ; 3.003 .550 \leq x \leq 4.200 .000 \\
1 ; x \geq 4.200 .000
\end{array}\right.
\end{aligned}
$$

Jika kebutuhan garam 4.200.000 ton, maka nilai keanggotaan ( $\left.\mu_{\text {Kebutuhan Garam }}[4.200 .000]\right)$ pada masing-masing himpunan adalah

$$
\begin{aligned}
& \mu_{\text {Kebutuhan Garam Rendah }}[4.200 .000]=0 \\
& \mu_{\text {Kebutuhan Garam Tinggi }}[4.200 .000]=1
\end{aligned}
$$

(iv) Produksi Garam Nasional

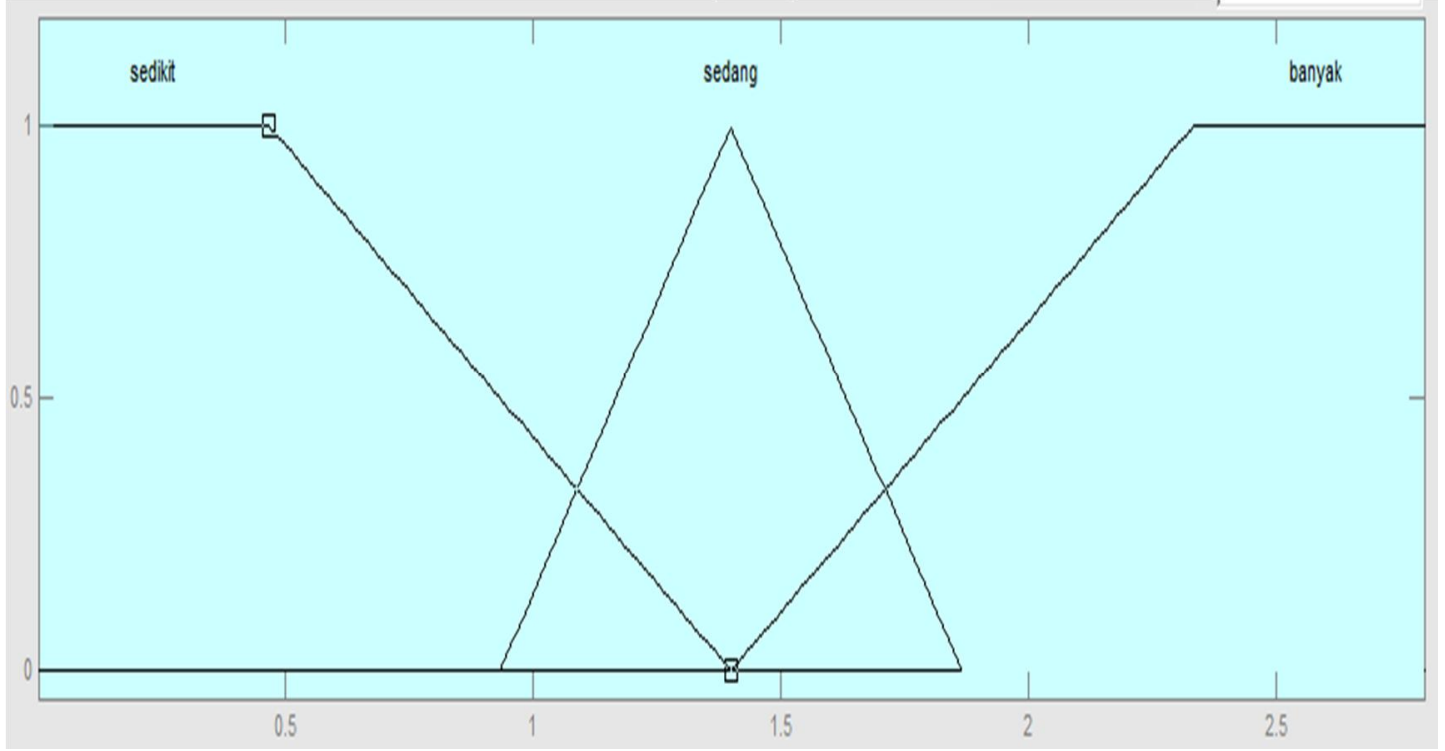

Gambar 5. Kurva Himpunan Fuzzy Untuk Variabel Produksi Garam Nasional Atau Representasi Variabel Produksi Garam Nasional

Fungsi keanggotaan:

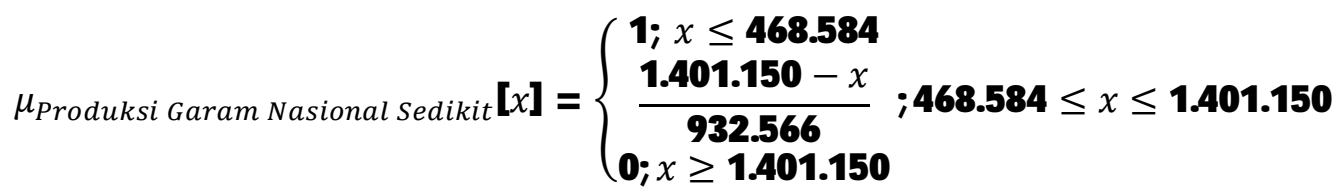




$$
\begin{aligned}
& \mu_{\text {Produksi Garam Nasional Sedang }}[x]=\left\{\begin{array}{c}
0 ; x \leq 934.867 \text { atau } x \geq 1.867 .434 \\
\frac{x-934.867}{466.283} ; 934.867 \leq x \leq 1.401 .150 \\
\frac{1.401 .150-x}{466.284} ; 1.401 .150 \leq x \leq 1.867 .434
\end{array}\right. \\
& \mu_{\text {Produksi Garam Nasional Banyak }}[x]=\left\{\begin{array}{l}
0 ; x \leq 1.401 .150 \\
\frac{x-1.401 .150}{932.568} ; 1.401 .150 \leq 2.333 .718 \\
1 ; x \geq 2.333 .718
\end{array}\right.
\end{aligned}
$$

Jika produksi garam nasional 2.775.447 Ton, maka nilai keanggotaan ( $\mu_{\text {Produksi Garam Nasional }}[2.775 .447]$ ) pada masing-masing himpunan adalah

$$
\begin{aligned}
& \mu_{\text {Produksi Garam Nasional }}[2.775 .447]=0 \\
& \mu_{\text {Produksi Garam Nasional }}[2.775 .447]=0 \\
& \mu_{\text {Produksi Garam Nasional }}[2.775 .447]=1
\end{aligned}
$$

b. Aplikasi Fungsi Implikasi

Pada tahap ini terdapat aturan berupa pernyataan-pernyataan kualitatif dalam bentuk IF THEN. Dari 3 variabel dan 11 himpunan, maka diperoleh 54 aturan. Fungsi Implikasi yang digunakan dalam proses ini adalah fungsi MIN yaitu dengan mengambil derajat keanggotaan minimum dari variabel input sebagai outputnya.

[1] IF curah hujan rendah AND luas lahan kecil AND kebutuhan garam rendah THEN produksi garam sedikit

[2] IF curah hujan rendah AND luas lahan kecil AND kebutuhan garam rendah THEN produksi garam sedang

[3] IF curah hujan rendah AND luas lahan kecil AND kebutuhan garam rendah THEN produksi garam banyak

[4] IF curah hujan rendah AND luas lahan kecil AND kebutuhan garam tinggi THEN produksi garam sedikit

[5] IF curah hujan rendah AND luas lahan kecil AND kebutuhan garam tinggi THEN produksi garam sedang

[6] IF curah hujan rendah AND luas lahan kecil AND kebutuhan garam tinggi THEN produksi garam banyak

[7] IF curah hujan rendah AND luas lahan sedang AND kebutuhan garam rendah THEN produksi garam sedikit

[8] IF curah hujan rendah AND luas lahan sedang AND kebutuhan garam rendah THEN produksi garam sedang

[9] IF curah hujan rendah AND luas lahan sedang AND kebutuhan garam rendah THEN produksi garam banyak

[10] IF curah hujan rendah AND luas lahan sedang AND kebutuhan garam tinggi THEN produksi garam sedikit

[11] IF curah hujan rendah AND luas lahan sedang AND kebutuhan garam tinggi THEN produksi garam sedang

[12] IF curah hujan rendah AND luas lahan sedang AND kebutuhan garam tinggi THEN produksi garam banyak

[13] IF curah hujan rendah AND luas lahan besar AND kebutuhan garam rendah THEN produksi garam sedikit

[14] IF curah hujan rendah AND luas lahan besar AND kebutuhan garam rendah THEN produksi garam sedang 
[15] IF curah hujan rendah AND luas lahan besar AND kebutuhan garam rendah THEN produksi garam banyak

[16] IF curah hujan rendah AND luas lahan besar AND kebutuhan garam tinggi THEN produksi garam sedikit

[17] IF curah hujan rendah AND luas lahan besar AND kebutuhan garam tinggi THEN produksi garam sedang

[18] IF curah hujan rendah AND luas lahan besar AND kebutuhan garam tinggi THEN produksi garam banyak

[19] IF curah hujan sedang AND luas lahan kecil AND kebutuhan garam rendah THEN produksi garam sedikit

[20] IF curah hujan sedang AND luas lahan kecil AND kebutuhan garam rendah THEN produksi garam sedang

[21] IF curah hujan sedang AND luas lahan kecil AND kebutuhan garam rendah THEN produksi garam banyak

[22] IF curah hujan sedang AND luas lahan kecil AND kebutuhan garam tinggi THEN produksi garam sedikit

[23] IF curah hujan sedang AND luas lahan kecil AND kebutuhan garam tinggi THEN produksi garam sedang

[24] IF curah hujan sedang AND luas lahan kecil AND kebutuhan garam tinggi THEN

Produlsi aram banyak.

[25] IF curah hujan sedang AND luas lahan sedang AND kebutuhan garam rendah THEN produksi garam sedikit

[26] IF curah hujan sedang AND luas lahan sedang AND kebutuhan garam rendah THEN produksi garam sedang

[27] IF curah hujan sedang AND luas lahan sedang AND kebutuhan garam rendah THEN produksi garam banyak

[28] IF curah hujan sedang AND luas lahan sedang AND kebutuhan garam tinggi THEN produksi garam sedikit

[29] IF curah hujan sedang AND luas lahan sedang AND kebutuhan garam tinggi THEN produksi garam sedang

[30] IF curah hujan sedang AND luas lahan sedang AND kebutuhan garam tinggi THEN produksi garam banyak

[31] IF curah hujan sedang AND luas lahan besar AND kebutuhan garam rendah THEN produksi garam sedikit

[32] IF curah hujan sedang AND luas lahan besar AND kebutuhan garam rendah THEN produksi garam sedang

[33] IF curah hujan sedang AND luas lahan besar AND kebutuhan garam rendah THEN produksi garam banyak

[34] IF curah hujan sedang AND luas lahan besar AND kebutuhan garam tinggi THEN produksi garam sedikit

[35] IF curah hujan sedang AND luas lahan besar AND kebutuhan garam tinggi THEN produksi garam sedang

[36] IF curah hujan sedang AND luas lahan besar AND kebutuhan garam tinggi THEN produksi garam banyak

[37] IF curah hujan tinggi AND luas lahan kecil AND kebutuhan garam rendah THEN produksi garam sedikit

[38] IF curah hujan tinggi AND luas lahan kecil AND kebutuhan garam rendah THEN produksi garam sedang

[39] IF curah hujan tinggi AND luas lahan kecil AND kebutuhan garam rendah THEN produksi garam banyak 
[40] IF curah hujan tinggi AND luas lahan kecil AND kebutuhan garam tinggi THEN produksi garam sedikit

[41] IF curah hujan tinggi AND luas lahan kecil AND kebutuhan garam tinggi THEN produksi garam sedang

[42] IF curah hujan tinggi AND luas lahan kecil AND kebutuhan garam tinggi THEN produksi garam banyak

[43] IF curah hujan tinggi AND luas lahan sedang AND kebutuhan garam rendah THEN produksi garam sedikit

[44] IF curah hujan tinggi AND luas lahan sedang AND kebutuhan garam rendah THEN produksi garam sedang

[45] IF curah hujan tinggi AND luas lahan sedang AND kebutuhan garam rendah THEN produksi garam banyak

[46] IF curah hujan tinggi AND luas lahan sedang AND kebutuhan garam tinggi THEN produksi garam sedikit

[47] IF curah hujan tinggi AND luas lahan sedang AND kebutuhan garam tinggi THEN produksi garam sedang

[48] IF curah hujan tinggi AND luas lahan sedang AND kebutuhan garam tinggi THEN produksi garam banyak

[49] IF curah hujan tinggi AND luas lahan besar AND kebutuhan garam rendah THEN produksi garam sedikit

[50] IF curah hujan tinggi AND luas lahan besar AND kebutuhan garam rendah THEN produksi garam sedang

[51] IF curah hujan tinggi AND luas lahan besar AND kebutuhan garam rendah THEN produksi garam banyak

[52] IF curah hujan tinggi AND luas lahan besar AND kebutuhan garam tinggi THEN produksi garam sedikit

[53] IF curah hujan tinggi AND luas lahan besar AND kebutuhan garam tinggi THEN produksi garam sedang

[54] IF curah hujan tinggi AND luas lahan besar AND kebutuhan garam tinggi THEN produksi garam banyak

Berdasarkan aturan yang sesuai dengan fungsi implikasi maka terdapat 53 aturan yang memiliki derajat keanggotaan nol dan 1 aturan dengan derajat keanggotaan 1 . Derajat keanggotaan 1 terdapat pada aturan ke - 18 yaitu IF curah hujan rendah AND luas lahan besar AND kebutuhan garam tinggi THEN produksi garam banyak.

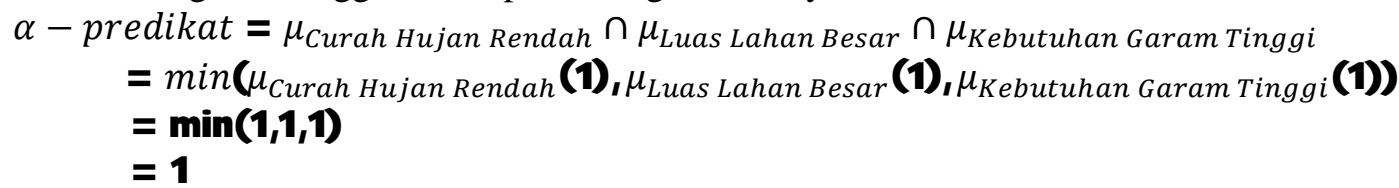

\section{c. Penegasan (defuzzy)}

Proses penegasan (defuzzyfikasi) menggunakan bantuan software Matlab dengan memanfaatkan fasilitas yang disediakan pada toolbox fuzzy. Pada tahap ini diperoleh prediksi jumlah garam nasional dengan menginput data curah hujan, luas lahan dan kebutuhan nasional. 


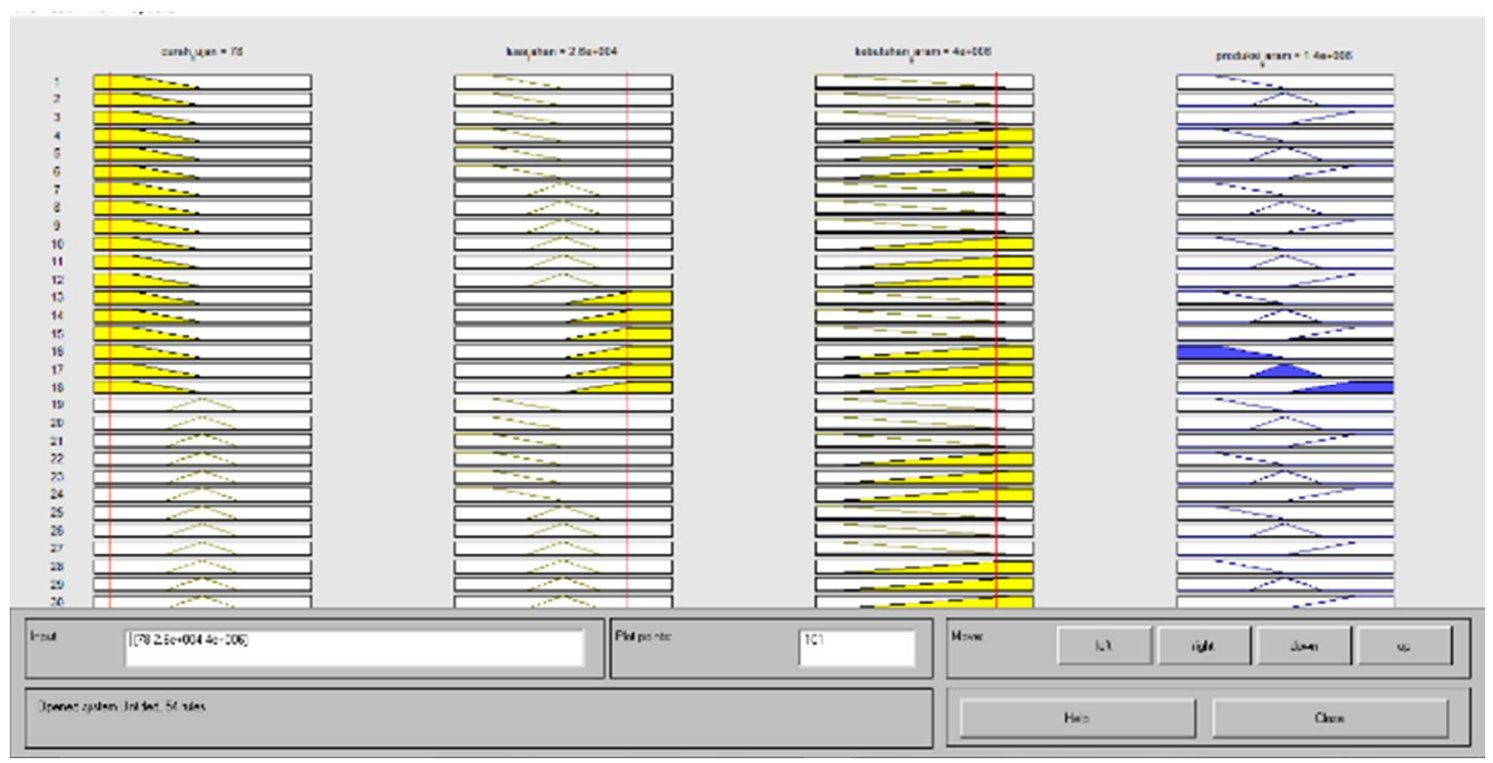

Gambar 6. Rule View (Hasil Optimasi Defuzzifikasi)

Sehingga dapat diperoleh hasil prediksi produksi garam nasional,

Tabel 4. Hasil Prediksi Produksi Garam Nasional

\begin{tabular}{|c|c|}
\hline Produksi Garam Nasional (Y) & $\begin{array}{c}\text { Prediksi Produksi } \\
\text { Garam Nasional } \\
\text { dengan Fuzzy ( }\end{array}{ }^{*}$ ) \\
\hline 30.600 & 1.400 .000 \\
\hline 1.113 .118 & 1.400 .000 \\
\hline 2.017 .601 & 1.400 .000 \\
\hline 1.087 .715 & 1.400 .000 \\
\hline 2.192 .168 & 1.400 .000 \\
\hline 2.800 .000 & 1.400 .000 \\
\hline 118.000 & 1.400 .000 \\
\hline 1.100 .000 & 1.400 .000 \\
\hline 2.300 & 1.400 .000 \\
\hline 2.775 .447 & 1.400 .000 \\
\hline
\end{tabular}

d. Menganalisa faktor - faktor yang mempengaruhi produksi garam nasional dengan Regresi Linier Berganda metode Kuadrat Terkecil.

Pada analisa regresi linier berganda metode kuadrat terkecil, persamaan regresi linier berganda $\left(\mathrm{Y}^{* *}\right)$ diperoleh dengan mengeliminasi persamaan-persamaan metode kuadrat terkecil (5). Koefisien $p_{0}, p_{1}, p_{2}$ dan $p_{3}$ diperoleh dengan bantuan software Minitab, seperti yang terlihat pada gambar dibawah ini: 


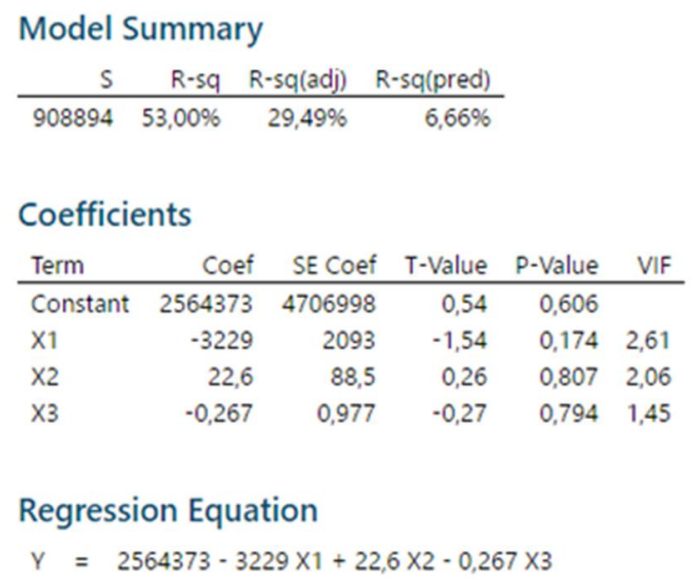

\section{Gambar 7. Nilai-nilai Koefisien Dengan Menggunakan Software Minitab}

Analisa yang dapat diberikan pada gambar diatas adalah $R-s q$ merupakan koefisien determinasi berganda [9]. $R-s q=53 \%$ berarti produksi garam nasional dapat dijelaskan oleh variabel independen curah hujan, luas lahan, dan kebutuhan garam secara serentak atau simultan sebesar 53\% sedangkan sisanya sebesar $47 \%$ lagi diterangkan oleh variabel lain diluar model yang tidak diteliti.

Variabel - variabel independen yang digunakan peneliti memberikan pengaruh yang besar dalam menentukan produksi garam nasional. Pertama curah hujan adalah faktor dari alam. Proses produksi garam memang sangat tergantung dari cuaca. Garam diproduksi dengan menguapkan air laut yang dipompa dilahan penggaraman. Kondisi cuaca menjadi salah satu penentu keberhasilan target produksi garam tetapi kondisi cuaca yang kurang stabil mengakibatkan produksi garam tidak stabil juga. Untuk mengantisipasi hal tersebut bantuan rekayasa iklim mikro pada areal penggaraman khusus angin, curah hujan, suhu dan kelembaban serta durasi penyinaran matahari perlu dilakukan agar evaporasi air garam dapat tercapai dan juga didukung oleh radiasi surya [10].

Faktor selanjutnya adalah luas lahan, di Indonesia petani garam umumnya melakukan usaha garam pada lahan sendiri. Sebahagian besar produksi garam di Indonesia dihasilkan oleh garam rakyat dengan luas areal rata - rata sebesar 0,5 - 3 hektar dengan letak yang terpencar pencar. Kondisi ini menyulitkan pengembangan garam dalam skala besar yang terintegrasi dan efisien membutuhkan kesatuan lahan datar yang cukup luas yaitu antara 4.000 - 6000 hektar sehingga akan mendapatkan manfaat dari skala ekonomi [1].

Variabel selanjutnya adalah kebutuhan garam, kebutuhan garam yang meningkat tiap tahunnya seharusnya menjadi motivasi bagi pihak terkait agar mampu menghasilkan garam dengan kuantitas dan kualitas yang diharapkan. Kebijakan - kebijakan yang di keluarkan pemerintah guna mendukung peningkatan kuantitas dan kualitas garam dalam negeri baik melalui intensifikasi seperti peningkatan teknologi, pengembangan sumber daya manusia dan perbaikan lembaga serta pembangunan infrastruktur disekitar tambak garam harus terus dilaksanakan. Melalui ekstensifikasi yaitu memanfaatkan lahan - lahan potensial sehingga produksi garam nasional dapat meningkat, memenuhi standar pasar dalam negeri dan luar negeri. Yang paling penting adalah meningkatkan pendapatan petani menuju peningkatan kesejahteraan keluarga sekaligus meningkatkan pendapatan nasional. 


\section{KESIMPULAN}

Dari pembahasan diatas dapat disimpulkan bahwa : logika fuzzy metoda mamdani dapat digunakan untuk memprediksi jumlah produksi garam nasional, pada kasus diatas penulis meramalkan produksi garam dalam rentang waktu 10 tahun dengan jumlah 1.400 .000 ton pertahunnya. Kedua, variabel independen yang digunakan yaitu curah hujan, luas lahan dan kebutuhan garam mampu menjelaskan variasi jumlah produksi garam sebesar 53\% sedangkan sisanya diterangkan oleh variabel lain. Karena itu ketiga faktor tersebut harus dioptimalkan melalui cara intensifikasi dan ekstensifikasi yang pastinya harus didukung dengan kebijakan kebijkan yang diterbitkan oleh pemerintah.

\section{SARAN}

Untuk penelitian selanjutnya penulis akan mencari variabel independen yang lain agar menghasilkan tingkat keakuratan yang lebih besar dalam meramalkan jumlah produksi garam nasional.

\section{UCAPAN TERIMA KASIH}

Terima kasih peneliti ucapkan kepada Direktorat Riset dan Pengabdian kepada Masyarakat Direktorat Jendral Penguatan Riset dan Pengembangan Kementrian Riset dan Teknologi atas pembiayaan yang diberikan pada penelitian ini. Semoga penelitian yang kami lakukan bermanfaat bagi kemajuan pendidikan dan kementerian yang terkait.

\section{DAFTAR PUSTAKA}

[1] Z. Salim and E. Munadi. 2016, Info Komoditi Garam.

[2] Y. R. Sari. 2018, Implementasi Program Pemberdayaan Usaha Garam di Desa Kedungmutih Kecamatan Wedung Kabupaten Demak Tahun 2011-2013, J. Spirit Publik.

[3] D. L. Rahakbauw, F. J. Rianekuay, and Y. A. Lesnussa, 2019, Penerapan Metode Fuzzy Mamdani Untuk Memprediksi Jumlah Produksi Karet (Studi Kasus: Data Persediaan dan Permintaan Produksi Karet pada PTP NUSANTARA XIV (PERSERO) Kebun Awaya, Teluk Elaputih, Maluku-Indonesia), J. Ilm. Mat. dan Terap. Vol. 16, No.1.

[4] Y. R. Sari, L. R. Ananda, and M. Rani, 2020, The Analysis of Fuzzy Logic Method and Multiple Linear Regression in Determining National Rice Production to Improve Food Self-Sufficiency in Indonesia, in IOP Conference Series: Materials Science and Engineering, doi: 10.1088/1757899X/846/1/012009.

[5] Y. R. Sari. 2018, Aplikasi Logika Fuzzy Metode Mamdani Dalam Menentukan Produksi Beras Tahun 2018 di Indonesia, Pros. SISFOTEK,

[6] M. Abrori and A. H. Prihamayu. 2015, Aplikasi Metode Fuzzy Mamdani Dalam Penentuan Jumlah Produksi, Kaunia.

[7] M. Rani, 2018, Logika Fuzzy Untuk Menentukan Asupan Kalori pada Terapi Diet Terhadap Penderita Obesitas, J. Inov. Tek. Inform., Vol. 1, No. 2, 
[8] S. E. Wati, D. Sebayang, and R. Sitepu, 2013, Perbandingan Metode Fuzzy Dengan Regresi Linier Berganda Dalam Peramalan Jumlah Produksi (Studi Kasus: Produksi Kelapa Sawit di PT. Perkebunan III (Persero) Medan Tahun 2011-2012), Saintia Mat.

[9] S. Suryati, F. Jalil, and S. Budi. 2016, Faktor-faktor yang Mempengaruhi Produksi Garam di Desa Matang Tunong, Agrifo J. Agribisnis Univ. Malikussaleh, doi: 10.29103/ag.v1i1.1083.

[10] Y. Adiraga and A. H. Setiawan. 2014, Analisis Dampak Perubahan Curah Hujan, Luas Tambak Garam dan Jumlah Petani Garam Terhadap Produksi Usaha Garam Rakyat di Kecamatan Juwana Kabupaten Pati Periode 2003-2012, Diponegoro J. Econ. 